\title{
Pembuatan Training Kit Pneumatik untuk SMKN I Ngawen Kabupaten Gunungkidul
}

\author{
Budi Basuki \\ Departemen Teknik Mesin, Sekolah Vokasi, Universitas Gadjah Mada \\ Email: ukicomp@yahoo.com
}

\begin{abstract}
Abstrak
Kegiatan Pengabdian Kepada Masyarakat (PKM), Departemen Teknik Mesin (DTM), Sekolah Vokasi, Universitas Gadjah Mada, Tahun 2015 adalah pembuatan training kit pneumatik untuk SMK N I Ngawen, Kabupaten Gunungkidul. Sekolah ini berada di Dusun Jono, Desa Tancep, Kecamatan Ngawen, Kabupaten Gunungkidul, memiliki lahan seluas $15.300 \mathrm{~m}^{2}$. Terdapat empat kompetensi keahlian yang diselenggarakan di sekolah ini, yaitu: Teknik Kendaraan Ringan, Alat Berat, Teknik Komputer dan Jaringan, dan Busana Batik. SMK N I Ngawen dan Sekolah Vokasi (dalam hal ini DTM sebagai Tim PKM yang terlibat langsung) telah menjalin kerjasama dalam bidang pendidikan alat berat. SMK N I Ngawen secara aktif telah memiliki perencanaan dan usaha pengembangan teknik kendali PLC sebagai sarana praktik untuk menunjang kompetensi keahlian alat berat. Setelah melakukan survei dan koordinasi dengan pihak Kepala Sekolah beserta staf-staf pendidiknya, kegiatan pengembangan teknik kendali PLC segera direncanakan meliputi penjadwalan, koordinasi pelaksanaan pelatihan PLC bagi staf pendidik, pengadaan unit PLC, pembuatan simulator training kit pneumatik dan kelengkapannya, administrasi kegiatan serta detail teknis. Rangkaian pengadaan sarana praktik teknik kendali PLC dan pembuatan training kit pneumatic berhasil dilaksanakan selama 6 (enam) bulan dengan lancar terhitung dari April hingga Oktober 2015. Kegiatan ini dilakukan di kampus DTM SV - UGM maupun di SMK N I Ngawen. Pelaksanaan pembuatan training kit ini dilakukan tim PKM dan staf-staf pendidik SMK N I Ngawen Gunungkidul. Pembuatan training kit pneumatik diawali dengan pembelian dan persiapan komponen-komponen training hingga penyusunan layout dan pengujian training kit. Penyerahan training kit pneumatik dilakukan setelah staf-staf pendidik SMK N I Ngawen Gunungkidul mengikuti pelatihan penggunaan training kit.
\end{abstract}

Kata kunci: pupuk kompos, bank sampah, sampah organik, sampah anorganik, memanen sampah.

\begin{abstract}
Community Service Activities (PKM) of Department of Mechanical Engineering (DTM), Vocational College, Universitas Gadjah Mada 2015 is entitled the development of pneumatic training kit for SMK N I Ngawen, Gunungkidul Regency. The school located in Jono Hamlet, Tancep Village, Ngawen District, Gunungkidul Regency, has a land area of 15,300 m2. There are four competency expertise held in this school, namely: Light Vehicle Technique, Heavy Equipment, Computer and Network Engineering, and Batik Clothing. SMK N I Ngawen and Vocational College (in this case Mechanical Engineering Department as a PKM team directly involved) have established cooperation in the field of heavy equipment education. SMK N I Ngawen actively has planning and effort of developing PLC control technique as a tool of practice to support the competence of machine expertise. After conducting surveys and coordination with the Principal and its staff, the PLC's control engineering development activities are planned to include scheduling, coordination of PLC training for educator staff, procurement of PLC units, the creation of pneumatic training kit simulators and completeness, the administration of activities and technical details. The procurement of PLC control techniques and pneumatic training kits was
\end{abstract}


successfully carried out for 6 (six) months smoothly from April to October 2015. This activity was conducted on campus of DTM SV - UGM and in SMK N I Ngawen. Implementation of this training kit was conducted by PKM team and education staffs of SMK N I Ngawen Gunungkidul. The preparation of pneumatic training kits begins with the purchase and preparation of training components to the preparation of layouts and testing of training kits. The delivery of pneumatic training kits was done after the teaching staffs of SMK N I Ngawen Gunungkidul attended training kit training.

Keywords: compost fertilizer, garbage bank, organic waste, inorganic waste, harvesting garbage.

\section{PENDAHULUAN}

Perkembangan di bidang kendali dan otomasi saat ini berkembang dengan cepat. Hal ini terjadi karena kebutuhan manusia yang menuntut terpenuhinya kebutuhan dengan cepat dan. Kecepatan dan produktivitas yang tinggi ini akan sangat sulit dicapai jika proses produksi masih menggunakan cara manual. Oleh karena hal tersebut maka kebutuhan peralatan otomasi merupakan hal yang sangat diperlukan guna meningkatkan efisiensi dan produktivitas suatu pekerjaan. Saat ini hampir semua mesin produksi telah menggunakan kendali otomatis atau semi otomatis untuk pengoperasiannya. Pengendalian mesin mesin-mesin tersebut dapat menggunakan logic relay, mikrokontroler, ataupun Programmable Logic Control (PLC). Pada kendali menggunakan logic relay sudah mulai ditinggalkan karena mempunyai banyak kelemahan, diantaranya adalah karena konsumsi listrik yang besar dan pengkabelan yang rumit.

Kendali menggunakan

mikrokontroler memiliki kelebihan yang tidak dimiliki oleh logic relay. Konsumsi listrik yang kecil, pengkabelan yang sederhana, harga yang murah untuk pengendalian yang kompleks, fleksibilitas, dan kelebihan-kelebihan lain. Karena mikrokontroler adalah sistem kontrol berbasis komputer yang merupakan hal baru, memunculkan kesulitan-kesulitan jika dibandingkan dengan sistem relay logic yang sudah dikenal lama. Serupa dengan mikrokontroler, PLC banyak digunakan sebagai kendali mesin-mesin industri. PLC merupakan kendali yang lebih mudah digunakan untuk otomasi namun menjadi sistem kontrol yang mahal.

Kendali otomasi ini bekerja berdasarkan input dan output suatu proses produksi. Sebagai input dapat berupa tegangan ataupun arus listrik yang dibangkitkan oleh sensor-sensor. Sedangkan output dapat berupa motor, transformator, relay, atau bahkan pneumatik dan hidrolik.

Saat ini rata-rata SMK (Sekolah Menengah Kejuruan) belum banyak membekali siswanya dengan kemampuan menangani sistem kendali berbasis komputer atau PLC, bahkan masih jarang sekali SMK yang memiliki konsentrasi di bidang kendali otomasi ini. Karena perkembangan teknologi kendali saat ini sangat cepat, maka siswa SMK juga dituntut untuk dapat mengikuti perkembangan tersebut.

Kegiatan Tim Pengabdian Kepada Masyarakat (PKM), Departemen Teknik Mesin, Sekolah Vokasi, Universitas Gadjah Mada, Tahun Anggaran 2015 ini dilaksanakan pada pembuatan training kit pneumatik untuk SMK N I Ngawen, Kabupaten Gunungkidul. Sekolah kejuaruan ini berada di Dusun Jono, Desa Tancep, Kecamatan Ngawen, Kabupaten Gunungkidul Yogyakarta, memiliki luas lahan seluas $15.300 \mathrm{~m} 2$. Kompetensi keahlian yang diselenggarakan di sekolah kejuruan ini terdapat emapt kompetensi, yaitu: Teknik Kendaraan Ringan, Alat Berat, Teknik Komputer dan Jariangan, dan Busana Batik. SMK N I Ngawen, Kabupaten Gunungkidul, Yogyakarta yang merupakan satu-satunya sekolah kejuruan yang memiliki kompetensi keahlian di bidang 
alat berat membutuhkan sarana praktik kendali otomasi. Praktik kendali ini dibutuhkan guna mendukung kompetensi keahlian tersebut mengingat peralatan alat berat tidak dapat dipisahkan dengan kendali otomasi. Oleh karena hal tersebut, maka Tim Pengabdian Kepada Masyarakat Departemen Teknik Mesin Sekolah Vokasi UGM yang telah memiliki kerjasama dibidang pendidikan alat berat dengan SMK $\mathrm{N}$ I Ngawen membuat media sarana praktik kontrol otomasi beserta simulasinya. Sarana praktik ini diwujudkan berupa alat praktik kontrol otomasi dan training kit pneumatik.

Bantuan sarana praktik kendali otomasi ini diharapkan akan dapat meningkatkan kompetensi keahlian di bidang alat berat SMK N I Ngawen, Kabupaten Gunungkidul, Yogyakarta. Pembuatan training kit pneumatik ini direncanakan untuk dapat mensimulasikan kendali otomasi yang terdapat pada peralatan alat berat.

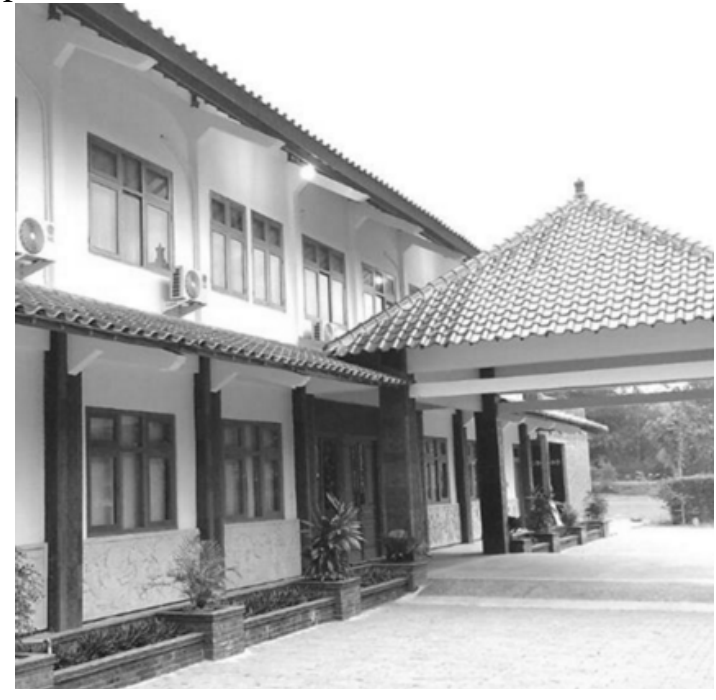

Gambar 1. SMK N I Ngawen, Kabupaten Gunungkidul, Yogyakarta

\section{Perumusan Masalah}

Berdasarkan pada pendahuluan yang telah diuraikan sebelumnya maka dapat dirumuskan permasalahan pada beberapa hal sebagai berikut:

1. Semakin banyak perusahaan yang bergerak di bidang industri, khususnya industri manufaktur yang menggunakan kendali otomasi untuk mesin-mesin produksinya
2. Perkembangan di bidang kendali dan otomasi yang cepat harus dapat diikuti oleh siswa SMK

3. Kemampuan siswa SMK yang masih minim mengenai kontrol dan otomasi.

4. Sarana penunjang proses pembelajaran perlu didukung adanya berbagai training kit yang relevan dengan kendali otomasi di industri.

\section{Tujuan Kegiatan}

Tujuan Kegiatan Pengabdian Kepada Masyarakat ini antara lain :

a. Menyediakan training kit sistem otomasi bagi sekolah SMK sebagai sarana proses pembelajaran kendali otomasi.

b. Memberikan pelatihan mengenai kendali otomasi yang dapat membantu siswa SMK dalam memahami sistem kendali dan otomasi saat ini.

c. Meningkatkan kemampuan siswa SMK dalam mengikuti perkembangan teknologi otomasi.

d. Mengenalkan Departemen Teknik Mesin Sekolah Vokasi UGM dan Sekolah Vokasi UGM kepada siswa SMK.

\section{Masalah}

Keberadaan praktik-praktik di sekolah kejuruan sangat diperlukan sehingga lulusannya memiliki ketrampilan yang mumpuni di bidangnya masingmasing. Teori-teori di kelas diajarkan sebagai pendukung kegiatan praktik bagi sekolah kejuruan sehingga keberadaan praktik-praktik sangat vital posisinya. Sarana praktik sudah seharusnya dapat dimanfaatkan dengan semaksimal mungkin. Namun perlu diketahui bahwa pengadaan peralatan-peralatan praktik tersebut membutuhkan waktu, usaha dan dana yang tidak sedikit untuk mewujudkannya.

Belum adanya sarana praktik kendali otomasi di SMK N I Ngawen Gunungkidul tentunya upaya mencapai proses transfer ilmu otomasi tidak berjalan dengan baik. Oleh karena hal tersebut, dalam rangka 
mendukung upaya Sekolah Vokasi UGM dalam membina kerjasama dengan SMK N I Ngawen Gunungkidul, Tim Pengabdian Kepada Masyarakat, Departemen Teknik Mesin, Sekolah Vokasi, UGM merancang kegiatan pembuatan training kit pneumatik. Dengan kegiatan ini diharapkan kualitas proses pembelajaran di sekolah kejuruan dapat meningkat.

Kegiatan pembuatan training kit pneumatik ini direncanakan berlangsung selama 5 (lima) bulan. Training kit pneumatik dibuat dalam bentuk alat peraga mekanisme menggunakan kontrol PLC untuk mengaktifkan aktuator pneumatik. Kegiatan berlangsung di Kampus Departemen Teknik Mesin SV-UGM dan SMK N I Ngawen, Kabupaten Gunungkidul, Daerah Istimewa Yogyakarta.

\section{METODE}

Realisasi kegiatan diawali dengan adanya survei lokasi dan menggali informasi oleh Tim Pengabdian Kepada Masyarakat Departemen Teknik Mesin, Sekolah Vokasi, UGM. Koordinasi dilakukan dengan pihak SMK N I Ngawen Gunungkidul mengenai rencana dan pelaksanaan kegiatan. Peralatan yang digunakan untuk pelaksanaan kegiatan pembuatan training kit ini menggunakan komponen-komponen yang dirancang dan disusun oleh tim pengabdian. Pengoperasian peralatan training kit pneumatik didahului dengan dilakukannya pelatihan PLC di Kampus Departemen Teknik Mesin SV-UGM selama 5 hari mulai pukul 7:0o hingga pukul 16:0o. Adapun tahapan pembuatan training kit pneumatik ini meliputi:

1. Perancangan training kit pneumatik yang meliputi tata letak komponenkomponen tarining.

2. Pembelian komponen-komponen training kit melalui on-line shop maupun melalui toko-toko retail.

3. Perakitan komponen-komponen training kit sesuai dengan tata letak yang telah dirancang.

4. Pengujian unjuk kerja dari training kit pneumatik menggunakan kendali PLC.
Labeling pada papan training kit untuk mempermudah dalam pengoperasian training kit.

\section{Manfaat Kegiatan}

Dengan adanya kegiatan Pengabdian Kepada Masyarakat ini diharapkan SMK N I Ngawen, Kabupaten Gunungkidul memperoleh manfaat-manfaat sebagai berikut:

a. Staf-staf pendidik dan siswa SMK bisa menggunakan training kit dalam mengontrol suatu sistem otomasi.

b. SMK N I Ngawen mampu menyediakan lulusan yang memiliki kompetensi keahlian di bidang alat berat dengan dukungan kemampuan kontrol otomasi.

c. Staf-staf pendidik dan siswa SMK dapat mengetahui dan mengenal Departemen Teknik Mesin Sekolah Vokasi UGM dengan baik.

\section{Khalayak Sasaran}

Sasaran kegiatan Tim Pengabdian Kepada Masyarakat Departemen Teknik Mesin, Sekolah Vokasi, UGM Tahun 2015 ini adalah Sekolah SMK N I Ngawen, Kabupaten Gunungkidul, D.I.Y. Melalui pembuatan training kit pneumatik ini diharapkan ketrampilan guru maupun siswa dalam bidang teknik kendalai otomasi dapat meningkat dan mampu memenuhi kebutuhan lulusan yang mahir dalam kendali otomasi.

\section{Metode Penerapan Ipteks}

Pembuatan training kit pneumatik ini dilakukan menggunakan komponenkomponen yang mudah didapatkan baik di lokal maupun nasional. Proses pembuatan training kit ini dilaksanakan dari bulan April hingga Oktober 2015. Adapun tahapan pembuatan training kit pneumatik ini meliputi: perancangan training kit pneumatik yang meliputi tata letak komponen-komponen tarining, pembelian komponen-komponen training kit melalui on-line shop maupun melalui toko-toko retail, perakitan komponen-komponen training kit sesuai dengan tata letak yang 
telah dirancang, pengujian unjuk kerja dari training kit pneumatik menggunakan kendali PLC, dan labeling pada papan training kit untuk mempermudah dalam pengoperasian training kit.

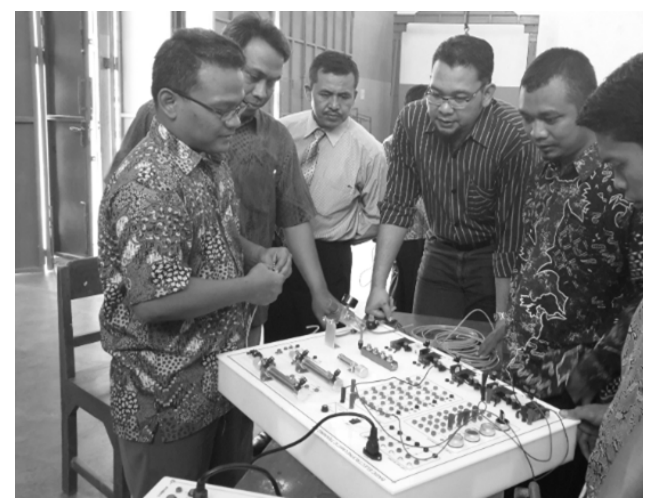

Gambar 2. Proses percobaan simulasi tarining kit pneumatik dengan staf-staf pendidik SMK N I Ngawen Kabupaten Gunungkidul Yogyakarta.

\section{Keterkaitan}

Hasil dari Kegiatan Pengabdian Kepada Masyarakat Departemen Teknik Mesin, Sekolah Vokasi, UGM Tahun Anggaran 2015 ini berupa pembuatan training kit pneumatik dalam bentuk alat peraga mekanisme menggunakan kontrol PLC untuk mengaktifkan aktuator pneumatik. Training kit ini direncanakan digunakan sebagai media praktik kendali otomasi di SMK N I Ngawen, Kabupaten Gunungkidul, DIY. Kegiatan ini dilaksanakan selama 6 (enam) bulan mulai dari bulan April hingga Oktober 2015.

Pembuatan training kit pneumatik dilakukan oleh tim Kegiatan Pengabdian Kepada Masyarakat Departemen Teknik Mesin, Sekolah Vokasi, UGM. Semua biaya yang timbul dalam kegiatan ini ditanggung oleh tim pengabdian (pembelian komponen-komponen pneumatik, biaya perakitan, pengujian, dll).

\section{Rancangan Evaluasi}

Evaluasi yang akan digunakan adalah kegiatan pembuatan peralatan simulasi pneumatik dan terealisasinya peraga praktik di SMKN I Ngawen sehingga dapat meningkatkan kualitas proses belajar mengajar.

\section{HASIL DAN PEMBAHASAN}

Kesulitan pertama yang timbul adalah koordinasi dengan pihak desa dimana dari pedukuhan yang ada, hanya satu dukuh yaitu dukuh Sendang rejo saja yang dapat melaksanakan sistem bank sampah ini dan berhasil memanen sampah, serta menyumbangkan hasil kegiatannya untuk membantu warga yang miskin, sehingga dapat meringankan kekurangannya. Namun demikian pengalaman ini akan menjadikan pengalaman kami bahwa mengorganisir suatu sistem bank sampah itu banyak kendalanya terutama dari pihak individunya. Perubahan alur pemikiran kadang harus mengalahkan gengsi dan strata kedudukan di masyarakat. Padahal fungsi sampah tidak hanya untuk dipanen dan menambah pendapatan tetapi juga dapat membuat lingkungan yang lebih sehat sehingga masalah kesehatan penduduk bisa lebih terjaga. Disamping itu pencemaran lingkungan dapat dikurangi bahkan dihilangkan sehingga tidak hanya manusianya yang sehat tetapi semua anggota ekosistem ikut terjaga, kesejahteraan masyarakat akan meningkat dan akan meningkatkan pendapatan. Dingawen akan timbul wirausaha wirausaha baru diantaranya pengepul sampah plastik juga produsen pupuk organik, sehingga bukan hanya lingkungan bersih tetapi juga lingkungan yang subur. Akhirnya semua potensi di desa dapat di olah menjadi barang yang menghasilkan dan mengurangi pengeluaran. 


\section{SIMPULAN}

Hasil dari Kegiatan Pengabdian Kepada Masyarakat Departemen Teknik Mesin, Sekolah Vokasi, UGM Tahun Anggaran 2015 ini berupa pembuatan training kit pneumatik dalam bentuk alat peraga mekanisme menggunakan kontrol PLC untuk mengaktifkan aktuator pneumatik. Training kit ini direncanakan digunakan sebagai media praktik kendali otomasi di SMK N I Ngawen, Kabupaten Gunungkidul, DIY. Kegiatan ini dilaksanakan selama 6 (enam) bulan mulai dari bulan April hingga Oktober 2015.

Pembuatan training kit pneumatik dilakukan oleh tim Kegiatan Pengabdian Kepada Masyarakat Departemen Teknik Mesin, Sekolah Vokasi, UGM. Semua biaya yang timbul dalam kegiatan ini ditanggung oleh tim pengabdian (pembelian komponen-komponen pneumatik, biaya perakitan, pengujian, dll).

\section{DAFTAR PUSTAKA}

Croser, P., Ebel, F. (2002). Pneumatics, Festo Didactic.

Ebel, F., et. all., (2009). Pneumatics Electropneumatics Fundamentals, Festo Didactic. 